\title{
Sintesis Lithium Bis Oksalato Borat untuk Elektrolit Baterai Lithium Ion
}

\author{
Etty Marti Wigayati \\ Pusat Penelitian Fisika - LIPI, Gd. 440 Kawasan PUSPIPTEK, Tangerang Selatan, Indonesia \\ E-mail: ettymw@yahoo.com
}

Masuk: 2 Februari $2018 \quad$ Direvisi : 21 Maret $2018 \quad$ Disetujui : 18 April 2018

\begin{abstract}
Abstrak: Telah dilakukan sintesis Lithium Bis Oksalato Borat (LIBOB). LiBOB merupakan bahan aktif yang dapat digunakan untuk elektrolit pada baterai Lithium. Metoda yang digunakan adalah reaksi fasa padat. Pada sintesis serbuk LiBOB, bahan awal $\mathrm{LiOH}, \mathrm{H}_{2} \mathrm{C}_{2} \mathrm{O}_{4} .2 \mathrm{H}_{2} \mathrm{O}$ dan $\mathrm{H}_{3} \mathrm{BO}_{3}$ (produk dari Merck dengan kemurnian 99,8\%) dicampur dengan perbandingan molar rasio 2:1:1 sampai homogen. Pemanasan awal pada temperatur $120^{\circ} \mathrm{C}$ selama 4 jam dilanjutkan pemanasan berikutnya pada temperatur $240^{\circ} \mathrm{C}$ selama 6 jam. Serbuk LiBOB yang dihasilkan dianalisa menggunakan XRD. Data yang diperoleh digunakan untuk menganalisis fasa yang terbentuk dan data kristalografi lainnya. Fasa major yang didapat adalah fasa $\mathrm{LiBOB}$ dan $\mathrm{LiBOB}$ hidrat. Hasil dari analisia spektroskopi FTIR pada rentang (400-4000) $\mathrm{cm}^{-1}$ menunjukkan ikatan gugus fungsi $\mathrm{LiB}\left(\mathrm{C}_{2} \mathrm{O}_{4}\right)_{2}$, dengan munculnya pita absorbsi C-O, C=O, B-O, O-B-O, dan C-C. Pita serapan O-B-O pada bilangan gelombang $1081 \mathrm{~cm}^{-1}$ merupakan salah satu ciri khas senyawa LiBOB. Selanjutnya dilakukan uji cyclic voltametric dengan cara serbuk LiBOB dilarutkan dalam pelarut karbonat dibuat baterai setengah sel diukur kurva CVnya, dimana hasilnya menunjukkan terjadi reaksi oksidasi-reduksi.
\end{abstract}

Kata kunci: LiBOB, reaksi fasa padat, struktur kristal, ikatan gugus, cyclic voltametric

\begin{abstract}
A synthesis process of lithium bis(oxalato) borate (LiBOB) has been conducted. LiBOB is one of lithium salts which is potentially viable to be utilized as an electrolyte material for solid lithium-ion battery. The method employed in the synthesis of $\mathrm{LiBOB}$ was solid state reaction. In the synthesis of $\mathrm{LiBOB}$ powder, $\mathrm{H}_{2} \mathrm{C}_{2} \mathrm{O}_{4} 2 \mathrm{H}_{2} \mathrm{O}$, $\mathrm{LiOH}$, and $\mathrm{H}_{3} \mathrm{BO}_{3}$ (from Merck with 98 $\%$ purity) were mixed with 2:1:1 mole ratio until homogeneous. The first heat preservation should be carried out at $120^{\circ} \mathrm{C}$ for 4 hours, and then heating temperature for preparing $L i B O B$ was at $240^{\circ} \mathrm{C}$ for 6 hours. The crystal structure of LiBOB powder formed from the heating process was analyzed with XRD. The data found were further explored to determine the phase formed, to calculate percentage of synthesized LiBOB from the crystallography data. The major phases formed were LiBOB and $L i B O B$-hydrate presented. The result of FTIR spectroscopy within wave number range of $400-4000 \mathrm{~cm}^{-1}$ confirmed that functional group of $\mathrm{LiB}\left(\mathrm{C}_{2} \mathrm{O}_{4}\right)_{2}$ compound was found, identified by the appearance of absorption band $C-O, C=O, B-O, O-B-$ $O$, and $C-C$, absorption band $O-B-O$ at wave number $1081 \mathrm{~cm}^{-1}$ which was one of typical peak of LiBOB compound. Furthermore, LiBOB powder was made into liquid electrolyte with carbonate-based solvent, and tested in a half cell lithiumion battery which is characterized on the CV curves, it was shown that an oxidation and reduction reaction occurs.
\end{abstract}

Keywords: LiBOB, solid phase reaction, crystal structure, cluster bond, cyclic voltametric

\section{PENDAHULUAN}

Baterai merupakan salah satu sumber energi yang berbasis elektrokimia yang banyak diperlukan di semua kegiatan. Sumber energi tersebut dipakai untuk menggerakkan benda dari yang sangat kecil sampai benda yang memerlukan daya besar seperti kendaraan listrik. Keuntungan menggunakan baterai adalah mudah dibawa dibandingkan menggunakan sumber energi yang lain. Ada berbagai jenis baterai antara lain lead acide, nickelcadmium (Ni-Cd), lithium, dan lain-lain. Teknologi baterai yang mendominasi pasar saat ini adalah baterai yang berbasis lithium [1]. Baterai ini pada umumnya menggunakan elektrolit polimer. Berbagai bahan aktif elektrolit digunakan dari garam lithium antara lain $\mathrm{LiPF}_{6}, \mathrm{LiClO}_{4}, \mathrm{LiAsF}_{6}, \mathrm{LiBF}_{4}$ dan $\mathrm{LiBOB}$ [2], dimana masing-masing memiliki kekurangan dan kelebihan. Secara skematis gambar baterai lithium[1] ditampilkan pada Gambar 1. Dari gambar tersebut dapat diketahui bahwa fungsi dari elektrolit pada baterai Lithium ion adalah media transfer ion Li dari katoda menuju anoda pada saat charge dan sebaliknya dari anoda menuju katoda pada saat discharge, 
sehingga garam Lithium merupakan komponen penting dalam elektrolit [3]. Untuk mendapatkan kapasitas yang optimal maka bahan elektrolit harus mempunyai sifat[1]: konduktivitas ionik yang tinggi, stabilitas elektrokimia baik, stabilitas kimia baik sehingga tidak reaktif terhadap elektroda dan separator dan ramah lingkungan.

Lithium bis (oxalato) Borate (LiBOB) merupakan garam litium baru diperkenalkan pertama kali pada tahun 1999 oleh Lischka et al [4,5] sebagai elektrolit yang sangat menjanjikan dan menguntungkan bagi baterai Li-ion isi ulang, sifat thermal pada LiBOB adalah hal yang menarik dan penting karena menyangkut keamanan baterai $\mathrm{Li}$ ion. Dalam beberapa tahun terakhir, beberapa peneliti telah mempublikasikan LiBOB antara lain studi thermal dari LiBOB, yang menunjukan perfoma bagus dari LiBOB sebagai elektrolit, stabilitas termal sampai sekitar $300^{\circ} \mathrm{C}$, diatas suhu ini, terdekomposisi menjadi $\mathrm{Li}_{2} \mathrm{CO}_{3}, \mathrm{~B}_{2} \mathrm{O}_{3}$ dan $\mathrm{CO}_{2}[2,6]$. Pada beberapa publikasi memaparkan elektrolit LiBOB dalam pelarut propilen carbonat (PC) mempunyai power capability yang besar dibanding garam Lithium yang lain [7]. Didapat pula pubikasi mengenai perfoma charge/discharge dari $0.7 \mathrm{M}$ LiBOB dalam pelarut EC:EMC(1:1) dibandingkan elektrolit 1M LiPF6 didalam pelarut EC:EMC (1:1) menunjukkan bahwa LiBOB lebih bagus pada discharge capacity pada temperatur tinggi, LiBOB bersifat lebih stabil[8]. LiBOB mempunyai beberapa sifat fisis antara lain hygroscopic, terdekomposisi secara perlahan bila kontak dengan air dan larut dengan baik pada campuran pelarut karbonat [9].

Penelitian LIBOB penting dilakukan karena LiBOB sebagai calon bahan pengganti LiPF6 yang sangat toxic dan berbahaya bagi kesehatan manusia. LiBOB mudah dibuat, ramah lingkungan dan lebih murah harganya. LiBOB sebagai larutan elektrolit pada baterai Li ion jauh lebih tinggi daripada garam Li lainnya (misalnya, LiPF6, LiBF4), sehingga akan memungkinkan baterai Li untuk beroperasi pada suhu tinggi, terutama yang dibutuhkan oleh kendaraan listrik hybrid (HEV) [6,10]. Struktur molekul LiBOB ditampilkan pada Gambar 2. Pada penelitian ini dipaparkan pembuatan LiBOB dengan metode reaksi fasa padat, kemudian dilakukan karakterisasi dengan XRD, FTIR dan LiBOB yang dihasilkan dibuat elektrolit cair yang dipergunakan pada baterai setengah sel kemudian diuji cyclic voltametric.



Gambar 1. Prinsip kerja baterai Lithium ion [1]

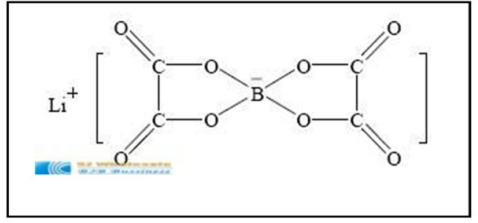

Gambar 2. Struktur molekul LiBOB

\section{METODOLOGI}

Metode yang dipergunakan pada sintesis LiBOB adalah reaksi fasa padat, skema reaksi kimia adalah sebagai berikut [11]:

$$
2 \mathrm{H}_{2} \mathrm{C}_{2} \mathrm{O}_{4} \cdot 2 \mathrm{H}_{2} \mathrm{O}+\mathrm{LiOH}+\mathrm{H}_{3} \mathrm{BO}_{3} \rightarrow \mathrm{LiB}\left(\mathrm{C}_{2} \mathrm{O}_{4}\right)_{2}+8 \mathrm{H}_{2} \mathrm{O}
$$

Bahan awal yang dipergunakan pada sintesa $\mathrm{LiBOB}$ adalah $\mathrm{LiOH}$, asam borat $\left(\mathrm{H}_{3} \mathrm{BO}_{3}\right)$ dan asam oksalat $\left(\mathrm{H}_{2} \mathrm{C}_{2} \mathrm{O}_{4} \cdot 2 \mathrm{H}_{2} \mathrm{O}\right)$. Bahan tersebut dari produk Merck dengan tingkat kemurnian lebih dari 99,8\%. Bahan awal ditreatment terlebih dahulu untuk menghilangkan uap air yang terikat dari udara. Bahan-bahan tersebut ditimbang dan dicampur berdasarkan rasio molar 2:1:1. Pemanasan dilakukan dalam furnace berbentuk mufle merek Thermoline.Temperatur pemanasan pada $120^{\circ} \mathrm{C}$ dengan durasi 4 jam, dan pada temperatur $240^{\circ} \mathrm{C}$, selama 6 jam. Hasil dari pemanasan berupa serbuk LiBOB berwarna putih.

Sampel kemudian dikarakterisasi, untuk mengetahui fasa yang terbentuk dengan alat XRD dari Rigaku tipe SmartLab, dengan target $\mathrm{CuK} \lambda$, panjang gelombang $\lambda=1,5406 \AA$ dengan rentang sudut 2 theta $10^{\circ}$ sampai $90^{\circ}$. Serbuk LiBOB diidentifikasi juga dengan spektroskopi FTIR merek Thermo Scientific Nicolet iS-10, untuk mengetahui ikatan gugus fungsi yang terbentuk. Analisa FTIR didapat spectrum infra merah dengan rentang bilangan gelombang 400-4000 $\left(\mathrm{cm}^{-1}\right)$. Uji elektrokimia dilakukan dengan cara melarutkan LiBOB dalam pelarut ethylene carbonate atau EC (Merck), diethyl carbonate atau DEC (Merck), dan ethyl methyl carbonate atau EMC ( Sigma Aldrich). Elektrolit cair disiapkan dengan melarutkan LIBOB dalam pelarut EC: EMC: DEC =1:1:1 (v/v) 
dengan konsentrasi $0.8 \mathrm{M}$ pada temperature $50^{\circ} \mathrm{C}$ selama 1 jam. Baterai setengah sel dibuat dengan menggunakan lithium ferro phosphate $\left(\mathrm{LiFePO}_{4}\right)$ komersial dari MTI sebagai katoda, lithium metal sebagai anoda, dan lembaran polyethylene (PE) sebagai separator. Keseluruhan proses dari pencampuran pelarut hingga penyusunan baterai setengah sel dilakukan di dalam glove box merek Vigor dengan aliran gas argon yang konstan yaitu tekanan 5 atmosfer dan debit aliran gas argon ditentukan oleh sistem kontrol glove box, untuk menjaga uap air dan oksigen dalam kondisi minimum. Analisis cyclic voltammetry $(\mathrm{CV})$ dilakukan dengan Wonatech Battery Cycler System WBCS -3000 .

\section{HASIL DAN PEMBAHASAN}

Hasil analisa XRD dari LiBOB powder berupa difraktogram ditampilkan pada Gambar 2. Terdapat 2 fasa yaitu fasa major $\mathrm{C}_{4} \mathrm{LiBO}_{8}(\mathrm{LiBOB})$ dan $\mathrm{LiB}\left(\mathrm{C}_{2} \mathrm{O}_{4}\right) 2\left(\mathrm{H}_{2} \mathrm{O}\right)(\mathrm{LiBOB}$ hidrat), tidak nampak muncul fasa minor yang lain sebagai impuritas karena yang dipergunakan bahan awal adalah bahan murni (pure analysis), dan bahan awal bereaksi semua. Hal ini bisa dilihat dari peneliti sebelumnya [12]. Berdasarkan data puncak sudut $2 \theta$ dan d yang telah dikeluarkan program PDF- 4 tahun 2013, didapatkan parameter kisi, dan data kristalografi lain yaitu struktur kristal, space group, densitas kristal maupun volume kristal yang ditampilkan pada Tabel 1.

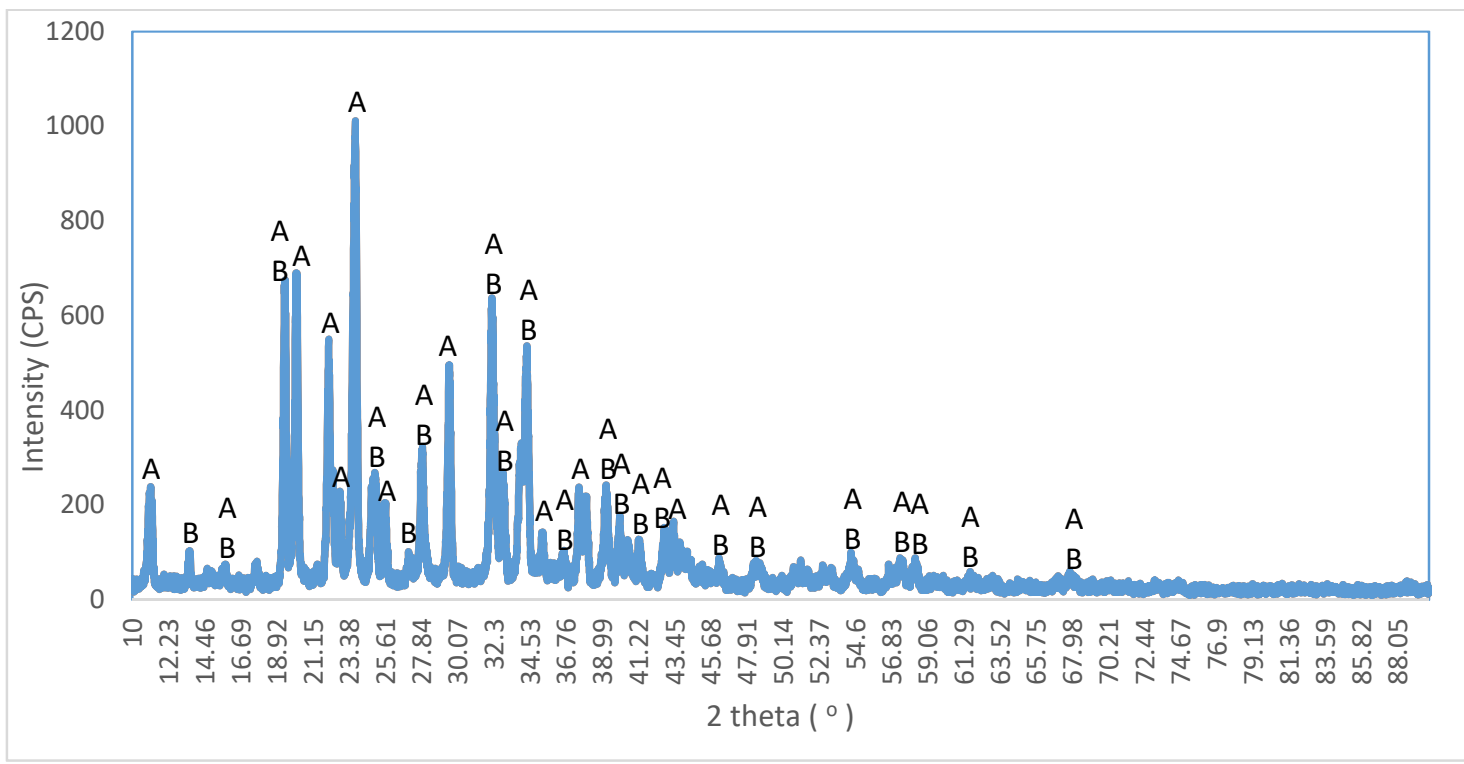

Gambar 3. Pola XRD LiBOB powder

Dari hasil analisis quantitative nampak pada fasa $\mathrm{LiB}\left(\mathrm{C}_{2} \mathrm{O}_{4}\right) 2\left(\mathrm{H}_{2} \mathrm{O}\right)$, LiBOB mengikat $\mathrm{H} 2 \mathrm{O}$ karena sifat higroskopis, hal ini terlihat jelas pada fasa $\mathrm{C}_{4} \mathrm{LiBO}_{8}$ volume kristalnya lebih kecil dibanding volume kristal $\mathrm{LiB}\left(\mathrm{C}_{2} \mathrm{O}_{4}\right) 2\left(\mathrm{H}_{2} \mathrm{O}\right)$, karena adanya molekul $\mathrm{H}_{2} \mathrm{O}$ didalam fasa $\mathrm{LiB}\left(\mathrm{C}_{2} \mathrm{O}_{4}\right)_{2}$. $\left(\mathrm{H}_{2} \mathrm{O}\right)$, sedang densitas kristal $\mathrm{C}_{4} \mathrm{LiBO}_{8}$ lebih besar dari $\mathrm{LiB}\left(\mathrm{C}_{2} \mathrm{O}_{4}\right)_{2} \cdot\left(\mathrm{H}_{2} \mathrm{O}\right)$, artinya kristal $\mathrm{C}_{4} \mathrm{LiBO}_{8}$ lebih tinggi/rapat. Dari data kristalografi yang diperoleh dari LiBOB powder hasil sintesis bila dibandingkan dengan data kristalografi hasil peneliti lain yang digunakan sebagai referensi $[13,14]$ menunjukkan kesesuaian hasil dari data kristalografi. 
Tabel 1. Data kristlografi hasil analisis LiBOB powder

\begin{tabular}{llcl}
\hline Fasa yang terbentuk & & Data kristalografi & \multicolumn{1}{c}{$\begin{array}{c}\text { Data kristalografi Reference } \\
{[13,14]}\end{array}$} \\
\hline $\mathrm{LiB}\left(\mathrm{C}_{2} \mathrm{O}_{4}\right)_{2} \cdot\left(\mathrm{H}_{2} \mathrm{O}\right)$ & Parameter kisi & $\mathrm{a}: 16.1410(\AA) ; \mathrm{b}: 15.937(\AA) ;$ & $\mathrm{a}: 16.075(\AA) ; \mathrm{b}: 15,880(\AA) ; \mathrm{c}:$ \\
& & $\mathrm{c}: 5.6237(\AA)$ & $5.6008(\AA)$ \\
& Struktur kristal & orthorombic & orthorombic \\
& Space group & Pbca & Pbca \\
& Volume kristal & $1446.7(\AA)^{3}$ & $1429.7(\AA)^{3}$ \\
& Density & $1.950\left(\mathrm{~g} / \mathrm{cm}^{3}\right)$ & $1.968\left(\mathrm{~g} / \mathrm{cm}^{3}\right)$ \\
\hline $\mathrm{C}_{4} \mathrm{LiBO}_{8}$ & Parameter kisi & $\mathrm{a}: 6.3719(\AA) ; \mathrm{b}: 7.6065(\AA) ;$ & $\mathrm{a}: 6.3635(\AA) ; \mathrm{b}: 75998(\AA) ;$ \\
& & $\mathrm{c}: 13.180(\AA)$ & $\mathrm{c} ; 13.1715(\AA)$ \\
& & $; \alpha=\beta=\gamma=90^{0}$ & \\
& Struktur kristal & Orthorombic & Orthorombic \\
& Space group & Pnma & Pnma \\
& Volume kristal & $638.8(\AA)^{3}$ & $636.99(\AA)^{3}$ \\
& Density & $2.023\left(\mathrm{~g} / \mathrm{cm}^{3}\right)$ & $2.021\left(\mathrm{~g} / \mathrm{cm}^{3}\right)$ \\
\hline
\end{tabular}

Dari analisa FTIR didapat spectrum infra merah dengan rentang bilangan gelombang 400-4000 $\left(\mathrm{cm}^{-1}\right)$ yang dapat dilihat pada Gambar 3. Dari data spectrum infra merah menunjukan gugus fungsi yang terdapat pada serbuk LiBOB. Keboleh jadian vibrasi yang dapat terjadi adalah gugus $\mathrm{C}-\mathrm{O}, \mathrm{C}=\mathrm{O}, \mathrm{B}-\mathrm{O}, \mathrm{O}-\mathrm{B}-\mathrm{O}$ dan $\mathrm{C}-\mathrm{C}$ yang merupakan gugus alkil, karbon. Bilangan gelombang $(1768-1808) \mathrm{cm}^{-1}$ merupakan vibrasi $\mathrm{C}=\mathrm{O}$ dan $994-1303 \mathrm{~cm}^{-1}$ merupakan vibrasi C-O-B-O-C. Bilangan gelombang $775 \mathrm{~cm}^{-1}$ merupakan salah satu puncak khas COO deform. Menurut literatur bahwa pita serapan yang harus nampak untuk senyawa $\mathrm{LiB}(\mathrm{C} 2 \mathrm{O} 4) 2$ yaitu pada bilangan gelombang $1372 \mathrm{~cm}^{-1}, 1087 \mathrm{~cm}^{-1}$ dan $860 \mathrm{~cm}^{-1}[15]$.



Gambar 4. Spektrum FTIR LiBOB powder

Untuk senyawa LiBOB menurut referensi[16] terlihat adanya regangan $\mathrm{C}=\mathrm{O}, \mathrm{B}-\mathrm{O}$ pada bilangan gelombang $1750 \mathrm{~cm}-1$ dan $1372 \mathrm{~cm}^{-1}$ dan regangan asymetric C-O-C pada bilangan gelombang $1008 \mathrm{~cm}-1$ sementara untuk LiBOB hasil sintesa tidak muncul, tetapi terdapat pita serapan O-B-O pada bilangan gelombang $1081 \mathrm{~cm}^{-1}$ yang merupakan salah satu ciri khas puncak senyawa LiBOB, pada referensi muncul pada bilangan gelombang 1070 $\mathrm{cm}^{-1}$. Pita serapan pada panjang gelombang $3511 \mathrm{~cm}^{-1}, 3412 \mathrm{~cm}^{-1}$ menunjukan adanya ikatan $\mathrm{OH}$. Adanya ikatan $\mathrm{OH}$ mengindikasikan bahwa kemungkinan masih adanya senyawa $\mathrm{B}(\mathrm{OH})_{3}$ maupun $\left(\mathrm{CO}_{2} \mathrm{H}\right)_{2}$ yang belum bereaksi sempurna. Atau mengikat $\mathrm{OH}$ dari udara karena sifat LiBOB adalah higroskopis. LiBOB yang terjadi mengikat 
gugus $\mathrm{OH}$ diudara membentuk $\mathrm{LiB}\left(\mathrm{C}_{2} \mathrm{O}_{4}\right) 2 .\left(\mathrm{H}_{2} \mathrm{O}\right)$, hal ini sesuai dengan hasil analisa XRD yang ditunjukan dengan fasa $\mathrm{LiB}\left(\mathrm{C}_{2} \mathrm{O}_{4}\right) 2 .\left(\mathrm{H}_{2} \mathrm{O}\right)$.

Hasil uji cyclic voltametric memberikan informasi mengenai besarnya arus, tegangan, dari baterai lithium untuk sel LiFePO4 /Li dengan menggunakan larutan elektrolit LIBOB ditampilkan pada Gambar 5. Kurva CV merepresentasikan proses elektrokimia baterai pada saat proses pengisian dan pemakaian. Kurva CV terdiri dari 2 puncak yaitu puncak oksidasi pada daerah arus positif dan puncak reduksi pada daerah arus negatif. Pada saat pemakaian (discharging) ion litium bergerak dari anoda ke katoda atau disebut sebagai puncak reduksi. Sebaliknya pada saat pengisian (charging) ion litium bergerak dari katoda ke anoda atau disebut puncak oksidasi semakin kecil jarak antar puncaknya maka semakin mudah ion litium bergerak dari anoda ke katoda atau sebaliknya. Dari kurva cyclic voltametric dapat diketahui nilai arus saat oksidasi 1,86 mA dan tegangan oksidasi 3,99 volt, sedang arus reduksi $-1,08 \mathrm{~mA}$ dan tegangan reaksi reduksi 2,72 volt. Besarnya selisih dari voltase ( $\Delta \mathrm{V}) 1,27$ volt menunjukkan reversibilitas ion (reversibilitas ion adalah fenomena kembalinya beberapa ion lithium ke struktur spinel saat proses discharging setelah sebelumnya terekstraksi saat proses charging pada katoda) $[17,18,19,20]$ selama reaksi redoks berlangsung yaitu mempunyai arus dan tegangan mendekati pada saat pemakaian dan pengisian sehingga elektrolit LiBOB dapat dipergunakan sebagai baterai.

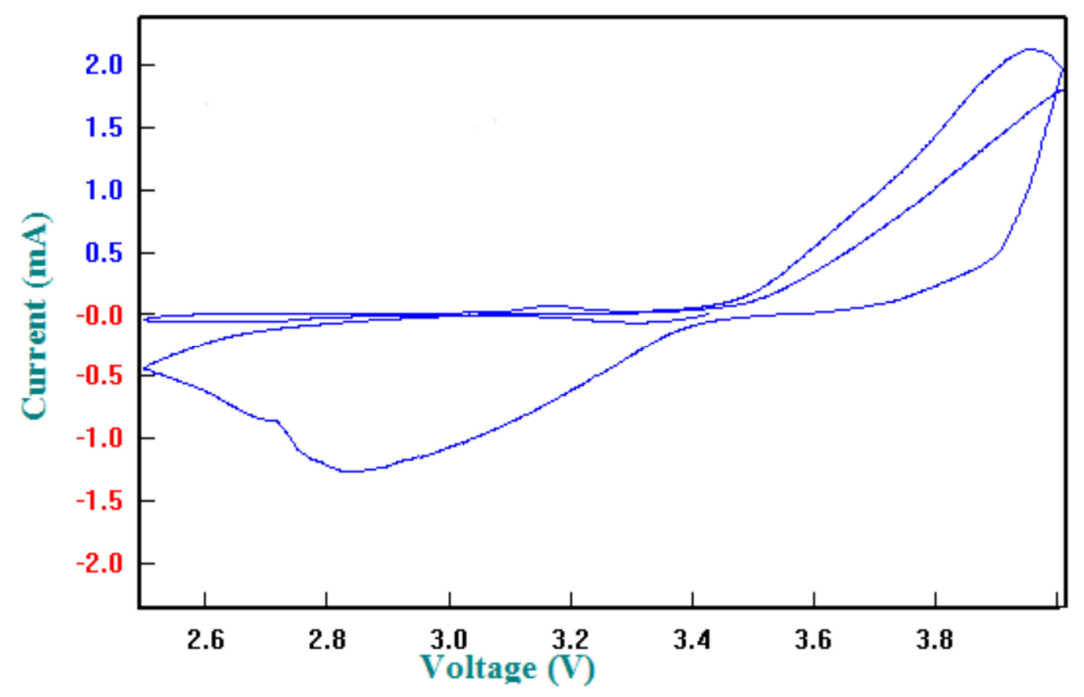

Gambar 5. Kurva cyclic voltametric sel LiFePO4 /Li dengan elektrolit LiBOB

\section{KESIMPULAN}

Pada sintesis LiBOB didapatkan karakteristik sebagai berikut: fasa LiBOB dengan struktur kristal orthorombic, space group Pbca, volume kristal $1446.7(\AA)$ dan density $1.950(\mathrm{~g} / \mathrm{cm} 3)$. Dan fasa $\mathrm{LiB}\left(\mathrm{C}_{2} \mathrm{O} 4\right) 2\left(\mathrm{H}_{2} \mathrm{O}\right)$ struktur kristal Orthorombic, space group Pnma, volume kristal $638.8(\AA)$ dan density 2.023(g/cm3). Dari analisis FTIR dapat diketahui terjadi adalah gugus $\mathrm{C}-\mathrm{O}, \mathrm{C}=\mathrm{O}, \mathrm{B}-\mathrm{O}, \mathrm{O}-\mathrm{B}-\mathrm{O}$ dan $\mathrm{C}-\mathrm{C}$ yang merupakan gugus alkil, karbon. Terdapat pita serapan O-B-O pada bilangan gelombang $1081 \mathrm{~cm}^{-1}$ yang merupakan salah satu ciri khas puncak senyawa LiBOB, pita serapan pada panjang gelombang $3511 \mathrm{~cm}^{-1}, 3412 \mathrm{~cm}^{-1}$ menunjukan adanya ikatan $\mathrm{OH}$. Hal ini menunjukkan terdapatnya LiBOB hidrat. Dari uji cyclic voltametric menunjukkan adanya reaksi oksidasireduksi dengan besar arus dan tegangan nilai arus saat oksidasi 1,86 mA dan tegangan oksidasi 3,99 volt, sedang arus reduksi $-1,08 \mathrm{~mA}$ dan tegangan reaksi reduksi 2,72 volt, dan menunjukkan sifat reversibilitas ion, sehingga dapat dipergunakan sebagai baterai.

\section{DAFTAR PUSTAKA}

[1] Linden D and Reddy T B 2011 Hand Book Of Batteries 4th ed. New York: McGraw-Hill

[2] Zinigrad E, Larush-Asraf L et al. 2007 Thermochimica Acta 64-69

[3] Tao H, Feng Z, Liu H, Kan X and Chen P 2011 The Open Material Science Journal 5204

[4] Lischka U, Wietelmann U and Wegner M 1999 Jerman Pat DE $19829030 \mathrm{C} 1$ 
[5] Xu W and Angel C A 2001 Electrochem. Solid-State Lett 4 E1-E4

[6] Cui X, Zhang H, Li S, Li X and Feng H 2014 Ionics 20(6) 789

[7] Kaneko H, Sekine K and Nakamura T 2005 Jurnal of Power Sources 146142

[8] Wang S, et al. 2007 Electrochemica Acta 524907

[9] Barth W V, Peña Hueso A, Zhou L, Lyons L J and West R 2014 J. Power Sources.

[10] Xu C K, Zhang S S, Jow T R, Xu W and Angel C A L 2002 Electrochem. Solid-State Lett 5 A26

[11] Liua Z, Chaia J, Xua G, Wanga Q and Cuia G 2015 Coordination Chemistry Reviews 29256

[12] Yu B -T, Qiu W -H, Li F -S and Li L -F 2007 Journal of Power Sources 1741012

[13] Zavalij P, Yang S and Whittingham M S 2004 Acta Cryst. B60 716

[14] Zavalij P, Yang S and Whittingham M S 2003 Acta Cryst. B59 753

[15] Moryc U and Ptak W.S 1999 Journal Molecule Structure. 511-512 241

[16] Aravindan V and Vickraman P 2009 Polymer Engineering \& Science 49(11) 2109

[17] Wang S, Qiu W, Guan Y, Yu B, Zhao H, Liu W 2007 Electrochimica Acta 524907

[18] Li S, Zhao Y, Shi X, Li B, Xu X, Zhao W and Cui X 2012 J. Electrochem. Sci. 65221

[19] Zhang L, Chai L, Zhanga L, Shen M, Zhang X, Battaglia V S, Stephenson T and Zheng H 2014 Electrochimica Acta 12739

[20] Zhang J W, Guo X, Yao S M and Qiu X P 2016 Science China Chemistry 59(11) 1479 